\title{
Mapping of profile students' metacognitive awareness in Yogyakarta, Indonesia
}

\author{
Sriyanto \\ SMAN 2 Bantul, Daerah Istimewa Yogyakarta, Indonesia \\ Email: Irsyanto2015@gmail.com \\ Moh Irma Sukarelawan* \\ Magister of Physics Education Program, Universitas Ahmad Dahlan, Indonesia \\ Email: moh.sukarelawan@mpfis.uad.ac.id
}

\begin{abstract}
This study aims to map the metacognitive awareness profile of students. Respondents involved were 198 students (24\% male and $76 \%$ female) who were spread in Grade X and XI Science. Respondents were selected using convenience sampling techniques at SMAN 2 Bantul in 2018/2019 Academic Year. Students' metacognitive awareness data were collected using the Jr. MAI developed by Kim et al. Students' metacognitive awareness data were analyzed descriptively and quantitatively. Results showed that female were more dominant having metacognitive awareness than male students. Overall, students already have good metacognitive awareness in knowledge and regulation aspects. Students' metacognitive knowledge were dominant distributed in Good (class X) and Very Good (class XI) category. While the Students' metacognitive regulations were dominant distributed in the Good category (class X and XI). The results of this study are expected to be used as a teacher's reference in designing effective teaching strategies to improve student academic achievement.
\end{abstract}

Keywords: metacognitive awareness, metacognitive mapping, metacognitive profile, metacognitive students

\section{Introduction}

One of the goals of the 2013 curriculum is for the high school students to have metacognitive competence [1]. Metacognitive is one of the foundations of Cognitive Hypothesis [2]. The Metacognitive Terminology was initiated by Flavel in 1976. This idea is the result of the research on children's memory in 1970 [3]. Flavel described metacognitive knowledge as individuals related to their own cognitive activity or everything related to it [4], [5]. However, along with the rapid research on metacognitive, various experts provide new definitions as a refinement of the original idea, for example, Daher, Anabousy, and Jabarin [6] define metacognition as cognition about cognition or knowledge about knowledge. In line with the definition from Van De Bogart, Dounas-Frazer, Lewandowski, \& Stetzer [7] interpret metacognition as thinking about one's thoughts. Metacognitive shows an individual's awareness of the structure and function of his own cognitive system, knowing what they are learning and how to learn it [8]. Another perspective, metacognitive awareness alludes to individuals' mindfulness of information of cognition relative to the individual, assignment, and procedure, and the self-control components they utilize to screen the method in a given setting [9]. Therefore, it can be concluded that metacognitive ability is a skill or capability possessed by someone in managing and controlling their cognitive dynamics that can affect how they learn effectively.

The metacognitive concept has been clarified by researchers through elaborations in several aspects. Braund and DeLuca [10] divide it into three aspects, namely: (a) Metacognitive Knowledge, (b) Metacognitive Regulation and (c) Metacognitive Experiences. However, most researchers divide it into two aspects [11], [12]. Two metacognitive aspects can be grouped into (a) Cognitive/Metacognitive Knowledge and (b) Cognitive/Metacognitive Regulation. Knowledge aspects of metacognitive include declarative, 
procedural, and conditional. Meanwhile, the regulatory aspects include planning, monitoring and evaluation [11], [13]-[15].

Metacognitive plays an active role in managing and controlling focus, selective perception, storing and managing short-term memory, coding and retrieval of long-term memory [3]. Various studies have shown the large role of metacognitive for students. Metacognitive can improve students' achievement and attitude [16]. For example, increased learning outcomes [17]-[20], problem solving abilities [21], [22], creative thinking [23] and conceptual understanding [24]. Coutinho [25] found a positive correlation between metacognitive abilities and academic achievement. The academic achievement of students who have high metacognitive would be better than students who have lower metacognitive [26]. The metacognitive awareness profile of students shows a description of themselves and the difficulties they encounter because they are not successful in solving problems [27]. The importance of the metacognitive role on student academic achievement is the main foundation of this topic studied. Until now, there has never been a mapping of students' metacognitive awareness in SMAN 2 Bantul. So the teacher is not optimal in designing appropriate learning strategies. Therefore, we feel the need to mapping the metacognitive awareness profile of students as preliminary information to design effective teaching strategies so that they can contribute to the world of education and teaching.

\section{Method}

\section{Responden}

This research belongs to the category of quantitative descriptive research using survey that had been conducted on students of SMAN 2 Bantul, Special Region of Yogyakarta. Students who have been involved as respondents are 198 people (24\% male and $76 \%$ female) with an age range from 16-18 years and an average age of 16.3 years. Respondents involved were scattered in Grade X IPA and Grade XI IPA even semester 2018/2019 Academic Year. Respondents were selected using convenience sampling techniques. The distribution of respondents in Grade X IPA consisted of $26 \%$ men and $74 \%$ women with an average age of 16.9 years and a standard deviation of 0.5 years. Whereas Grade XI Natural Sciences consists of $23 \%$ men and $77 \%$ women with an average age of 15.9 years and standard deviations of age of 0.5 years.

\section{Instrument}

To capture the metacognitive awareness data of SMAN 2 Bantul students, researchers have adopted the Jr.MAI (Junior Metacognitive Awareness Inventory) metacognitive awareness instrument developed by Kim et al., [5]. Metacognitive awareness consists of two subscales, namely Metacognitive Knowledge and Metacognitive Regulation. Metacognitive knowledge consists of declarative knowledge, procedural knowledge and conditional knowledge. Whereas metacognitive regulation includes planning, monitoring and evaluation. Jr. MAI has been tested and analyzed by Kim et al., through exploratory factor analysis and confirmatory factor analysis techniques. A total of 18 items of the Jr. MAI scale ( 9 items of MK and 9 items of MR) adopted have good validity and reliability [5] so that they can be used as instruments to explore information in describing students' metacognitive awareness profiles. Jr. MAI which has been used, has been examined by 2 senior English lecturers to ensure the suitability of the meaning of each item. Jr. MAI uses a Likert scale of 1 to 5 as in Table 1.

Table 1. Likert scale

\begin{tabular}{cc}
\hline Code & Scoring \\
\hline Never & 1 \\
\hline Rarely & 2 \\
\hline Sometimes & 3 \\
\hline Often & 4 \\
\hline Always & 5 \\
\hline
\end{tabular}




\section{Data Collection and Analysis}

The metacognitive awareness data collection for students of SMAN 2 Bantul was done online by using the Google form. This was done to facilitate administration and analysis of responses from respondents. Before filling out the questionnaire, students were made aware that all the responses they provide would not affect academic grades directly. This was done so students can respond naturally, honestly and as it is. So that, in the end, the metacognitive awareness profile of students can describe the real situation.

To get the metacognitive awareness profile of students, the data were analyzed using quantitative descriptive analysis techniques. The analysis has been done by comparing metacognitive awareness of the criteria that have been determined, then determined the percentage. Categorization has been divided into five levels, each spacing 1.5 Sbi [28]. The number of items in the second subscale is 9 points each so that the evaluation criteria are the same, referring to Table 2.

Table 2. Metacognitive awareness assessment criteria (MK/MR)

\begin{tabular}{rc}
\hline Score Range & Category \\
\hline $\mathbf{X}>\mathbf{3 6}$ & Very Good \\
\hline $\mathbf{3 0}<\mathbf{X} \leq 36$ & Good \\
\hline $\mathbf{2 4}<\mathbf{X} \leq 30$ & Fair \\
\hline $\mathbf{1 8}<\mathbf{X} \leq 24$ & Poor \\
\hline $\mathbf{X} \leq 18$ & Very lacking \\
\hline
\end{tabular}

\section{Result and Discussion}

This research has produced a metacognitive awareness mapping of Grade X and XI science students of SMAN 2 Bantul. Data on students' metacognitive awareness responses were obtained through filling out a Jr. MAI questionnaire that had been developed by Kim et al. [5]. Metacognitive awareness is divided into two aspects, namely Metacognitive Knowledge (MK) and Metecognitive Regulation (MR) [12].

\section{Metacognitive Knowledge (MK)}

Figure 1 shows the results of the analysis of the level of metacognitive knowledge possessed by Grade $\mathrm{X}$ and XI students in 2018-2019 Academic Year.

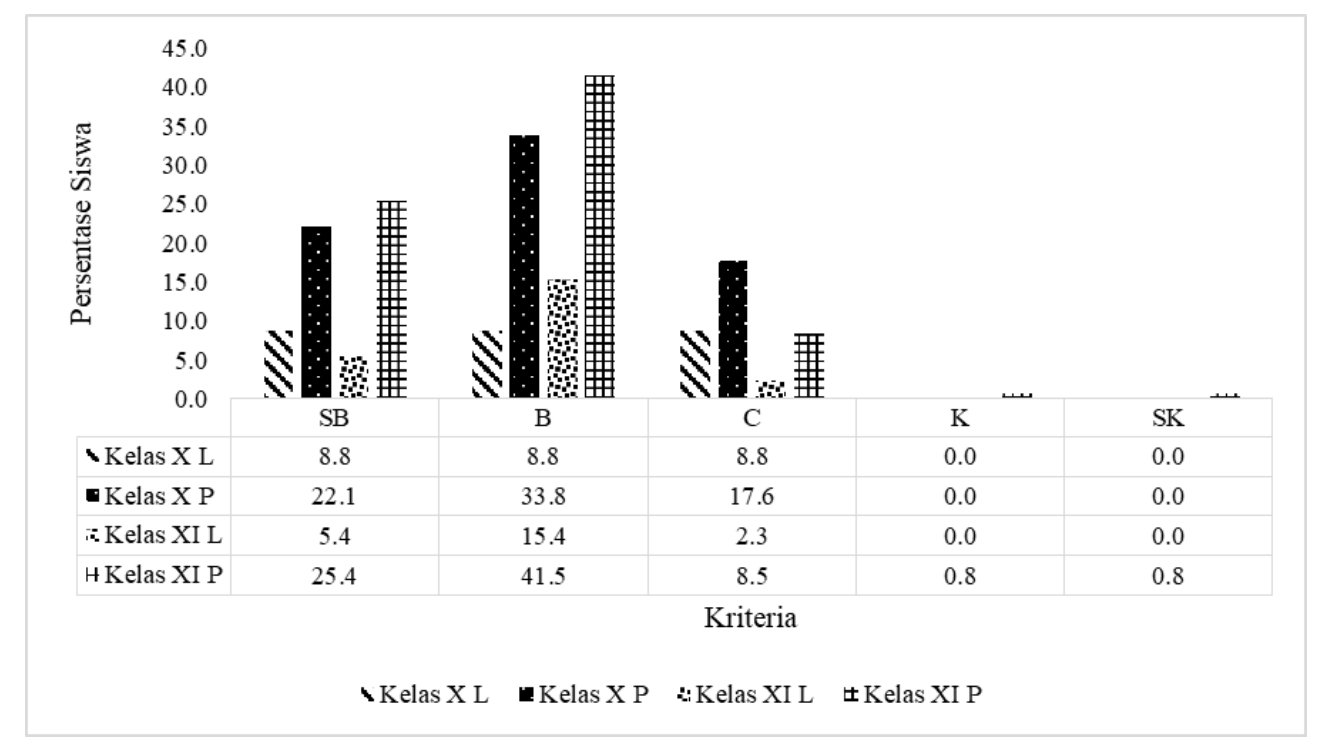

Figure 1. Students Metacognitive Knowledge 
Based on Figure 1, most students already have good metacognitive knowledge. This can be seen from the percentage of students who were in Good (42.6\%), Very Good (30.9\%) and Fair categories (26.5\%) for Grade X students. Grade XI students also showed a distribution in Good (56.9\%), Very Good (30.8\%) and Fair categories $(10.8 \%)$.

Figure 1 reviewed by gender, female students have a more dominant metacognitive knowledge than male students. For example in the Fair category in grade X, the percentage of female students is twice as high as that of male students. Very Good Category XI and Good Category XI, the percentage of female students is three times more than male students. Both in grade $\mathrm{X}$ and category fair in Grade XI, the percentage of female students is four times more than male students. Even in the Very Good category in class XI, the percentage of female students was five times more than male students. Meanwhile, students who are in the category of poor and very lucking are almost none except female students in Grade XI by $0.8 \%$. This finding is not in line with the findings of [29]. He has found that metacognitive knowledge profiles between female and male students are in the low category. This means that there are no differences in metacognitive knowledge between female and male students.

Metacognitive knowledge describes the knowledge possessed by individuals in considering, controlling and understanding goals and strategies in order to complete a task [11], [30]. In general, students' metacognitive knowledge is good. This shows that generally Grade X and Grade XI students already have the knowledge to consider, control and understand learning goals and strategies. Students already have declarative knowledge in understanding the factual knowledge needed before it is processed or critical thinking skills are used related to the given topic. In addition, students also have procedural knowledge to understand how to apply a learning procedure or strategy. Students already have conditional knowledge to determine the right time and reason in applying their knowledge and skills [31]-[33].

\section{Metacognitive Regulation (MR)}

Figure 2 shows the results of the analysis of the level of metacognitive regulation possessed by students in Grade X and XI in Academic Year 2018-2019.

Based on Figure 2, students are generally accustomed to using regulations or metacognitive skills in learning or to solve tasks/problems encountered. This is supported by student response data showing metacognitive regulation distributed in the categories Very Good, Good and Fair with the percentages respectively $19.1 \%, 42.6 \%$ and $32.4 \%$ for class X. while in class XI with a percentage of $31.5 \%$ each, $45.4 \%$ and $21.5 \%$. As for the category of Poor it is only $5.9 \%$ for class X and $1.5 \%$ for class XI.

Based on gender, the percentage of male students who apply metacognitive regulation in learning is lower when compared to female students. This statement is supported by the data shown in Figure 2. For example, the percentage of Good Female category students in class $\mathrm{X}$ is twice as high as male students. Very Good Category in Grade XI reached seven times more. Even in Grade X in the Very Good category, the percentage of female students reached twelve times more when compared to male students. Whereas in the category of Poor, the percentage of female students was three times more. This finding is different from the findings obtained by [34]. They have found no differences in metacognitive regulation between female and male students 


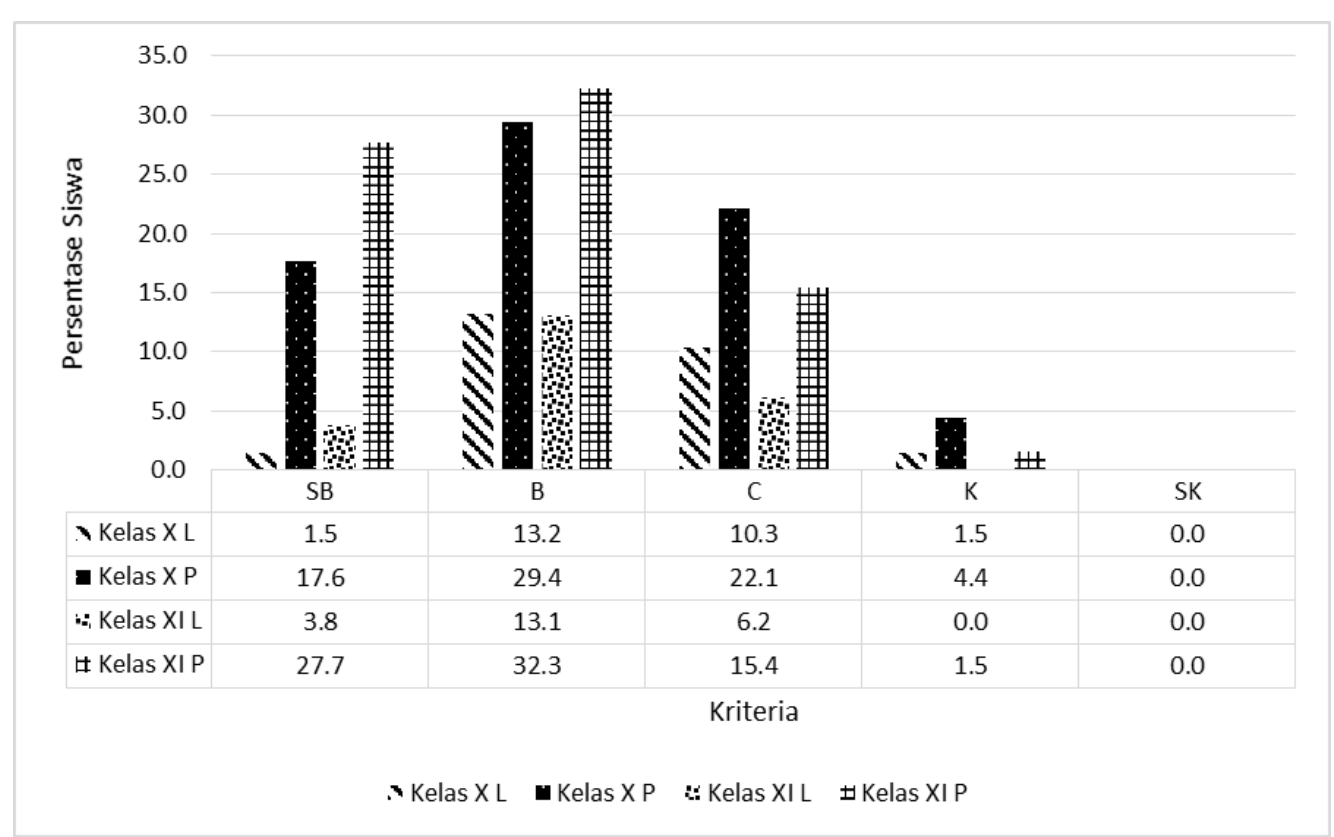

Figure 2. Students Metacognitive Regulation

Metacognitive regulation or metacognitive ability is a sequence of activities or actions carried out by individuals in controlling their thinking or learning [15]. Based on the research results obtained, the dominant students both Grade X and Grade XI already have good metacognitive abilities. This shows that Grade X and Grade XI students are able to plan, carry out monitoring and evaluate when they solve problems when implementing learning. The ability of students to make plans is very necessary for students when solving problems in learning. Students can identify the problems faced, choose and sort information that is needed or not needed in solving problems so that the problem to be solved becomes more directed. The ability to carry out monitoring of learning by students encourages them to assess the significance of the learning strategies that have been used. Meanwhile, the ability to carry out evaluations supports them in analyzing how effective the learning strategies they have applied in the learning process.

Based on the categorization of students' metacognitive awareness have been done, the percentage of students who have low metacognitive awareness is very minimal. This low percentage is due to the fact that each individual has begun to develop metacognitive awareness since childhood and start optimal when cognitive has reached the formal operational stage [34].

The results showed that there were differences in metacognitive awareness between female and male students. The percentage of metacognitive awareness of female students is higher than male students. These findings are in line with the results of research conducted by Nurmaliah [35] and Syarifah, Indriwati, \& Corebima [36]. Female students are better able to think and regulate their way of thinking so that it has implications for the high learning outcomes. Female students are more critical in responding to questions or provide feedback on the issues discussed. Their motivation in learning science is very high so they are more focused and serious when discussing. Whereas male students are more likely to relax and play more.

Mahanal [37] has found that the critical thinking ability of male students is lower than that of female students because of the role of language skills. Students who have high language skills tend to be able to make conclusions, form hypotheses and consider relevant information [37]. Brain regions associated with language function in women work harder when compared to men so that women's language skills are better [37]. Students who have good language skills tend to have high-level critical thinking skills because Language is a tool used to convey thoughts [34]. Thinking activities in answering questions can practice skills in planning and self-monitoring. The skill of planning and self-monitoring is an element of metacognitive awareness [34].

Other studies have found different things. Metacognitive awareness does not differ significantly by gender [34], [38]. No significant difference in metacognitive awareness based on gender due to the use of a learning model that is able to minimize gender differences, so that female and male students can have an equivalent metacognitive awareness [34]. 
Women and men have different learning potential. As a teacher, it must be responded wisely. Teachers must be able to develop learning that can minimize gender differences by providing different strategies between men and women [34].

\section{Conclusion}

Based on the results that have been reviewed and discussed, the mapping of metacognitive awareness profile of SMAN 2 Bantul students is mostly in the Good category. Students still had low metacognitive awareness around 5\%. When viewed from a gender perspective, the percentage of female students having a metacognitive awareness was higher than that of male students. However, to keep the quality of learning always effective, practicing metacognitive abilities for students must still be implemented.

\section{References}

[1] Kemendikbud, "Salinan Peraturan Menteri Pendidikan Dan Kebudayaan Republik Indonesia Nomor 37 Tahun 2018." Jakarta, 2018.

[2] C. K. Altundağ, "Context-Based Chemistry Teaching within the 4Ex2 Model: Its Impacts on Metacognition, Multiple Intelligence, and Achievement," J. Turkish Sci. Educ., vol. 15, no. 2, pp. 1-12, 2018.

[3] M. Altindağ and N. Senemoğlu, "Metacognitive Skills Scale," H. U. J. Educ., vol. 28, no. 1, pp. 15-26, 2013.

[4] F. Cubukcu, "Metacognition in the classroom," Procedia - Soc. Behav. Sci., vol. 1, no. 1, pp. 559-563, 2009.

[5] B. Kim, B. Zyromski, M. Mariani, S. M. Lee, and J. C. Carey, "Establishing the factor structure of the 18-item version of the junior metacognitive awareness inventory," Meas. Eval. Couns. Dev., vol. 50, no. 1-2, pp. 48-57, 2017.

[6] W. Daher, A. Anabousy, and R. Jabarin, "Metacognition, Positioning and Emotions in Mathematical Activities," Int. J. Res. Educ. Sci., vol. 4, no. 1, pp. 292-303, 2018.

[7] K. L. Van De Bogart, D. R. Dounas-Frazer, H. J. Lewandowski, and M. R. Stetzer, "Investigating the role of socially mediated metacognition during collaborative troubleshooting of electric circuits," Phys. Rev. Phys. Educ. Res., vol. 13, no. 2, pp. 1-19, 2017.

[8] Y. Coşkun, "A Study on Metacognitive Thinking Skills of University Students," J. Educ. Train. Stud., vol. 6, no. 3, pp. 38-46, 2018.

[9] E. Adadan and D. Oner, "Examining Preservice Teachers' Reflective Thinking Skills in the context of WebBased Portfolios: The Role of Metacognitive Awareness," Aust. J. Teach. Educ., vol. 43, no. 11, pp. 26-50, 2018.

[10] H. Braund and C. DeLuca, "Elementary students as active agents in their learning: an empirical study of the connections between assessment practices and student metacognition," Aust. Educ. Res., vol. 45, no. 1, pp. 6585, 2018.

[11] B. Çetin, "Metacognition and Self-regulated Learning in Predicting University Students' Academic Achievement in Turkey," J. Educ. Train. Stud., vol. 5, no. 4, 2017.

[12] A. González, M.-V. C. Fernández, and P.-V. Paoloni, "Hope and anxiety in physics class: Exploring their motivational antecedents and influence on metacognition and performance," J. Res. Sci. Teach., vol. 54, no. 5, pp. 558-585, 2017.

[13] S. Altık, Z. Başer, and E. Yükseltürk, "Enhancing metacognitive awareness of undergraduates through using an e-educational video environment," Comput. Educ., vol. 139, no. May, pp. 129-145, 2019.

[14] M. A. Küçükaydın, "The Effect of Fifth- Grade Students' Science Anxiety on Metacognitive Awareness," J. Balt. Sci. Educ., vol. 17, no. 5, pp. 878-886, 2018.

[15] M. Mahdavi, "An Overview: Metacognition in Education," Int. J. Multidiscip. Curr. Res., vol. 2, no. Juni, pp. 529-535, 2014

[16] S. M. SahIn and F. Kendir, "The Effect of Using Metacognitive Strategies for Solving Geometry Problems on Students' Achievement and Attitude," Educ. Res. Rev., vol. 8, no. 19, pp. 1777-1792, 2013.

[17] W. Hermawan, Z. Abidin, and E. Junaedi, "Peran Gender dan Kesadaran Metakognitif Siswa SMA Di Kabupaten Kuningan Terhadap Hasil Belajar Biologi," Quagga J. Pendidik. dan Biol., vol. 10, no. 2, pp. 11-18, 2018.

[18] T. Khoiriah, "Strategi Pembelajaran Metakognitif Terhadap Hasil Belajar Siswa pada Konsep Sistem Pencernaan pada Manusia," J. Pengajaran Mat. dan Ilmu Pengetah. Alam, vol. 6, no. 1, p. 177, Sep. 2015.

[19] V. Panggayuh, "Pengaruh Kemampuan Metakognitif Terhadap Prestasi Akademik Mahasiswa pada Mata Kuliah Pemrograman Dasar,” J. Ilm. Penelit. dan Pembelajaran Inform., vol. 02, no. 01, pp. 20-25, 2017.

[20] W. Tamsyani, "Pengaruh Model Pembelajaran dan Kesadaran Metakognitif Terhadap Hasil Belajar Peserta Didik SMA dalam Materi Pokok Asam Basa,” J. EST, vol. 2, no. 1, pp. 10-25, 2016. 
[21] N. Solikhah, E. R. Winarti, and A. W. Kurniasih, "Keefektifan Model Guided Inquiry dengan Pendekatan Keterampilan Metakognitif terhadap Kemampuan Pemecahan Masalah,” J. Kreano, vol. 5, no. 1, pp. 18-25, 2014.

[22] Nurhayati, A. Hartoyo, and Hamdani, "Kemampuan Metakognisi Siswa dalam Pemecahan Masalah pada Materi Bangun Datar Di Kelas VII SMP,” J. Pendidik. dan Pembelajaran Untan, pp. 1-13, 2017.

[23] S. Suprapto, S. Zubaidah, and A. D. Corebima, "Pengaruh Gender terhadap Keterampilan Berpikir Kreatif Siswa pada Pembelajaran Biologi," J. Pendidik. Teor. Penelitian, dan Pengemb., vol. 3, no. 3, pp. 325-329, 2018.

[24] B. H. Siswati, H. Susilo, and S. Mahanal, "Pengaruh Gender terhadap Keterampilan Metakognitif dan Pemahaman Konsep Peserta Didik IPA dan Biologi di Malang," in Prosiding Semnas Pend. IPA Pascasarjana $U M, 2016$.

[25] S. A. Coutinho, "The Relationship Between Goals, Metacognition, and Academic Success," Educate, vol. 7, no. 1, pp. 39-47, 2007.

[26] A. Muhlisin, H. Susilo, M. Amin, and F. Rohman, "The Effectiveness of RMS Learning Model in Improving Metacognitive Skills on Science Basic Concepts," J. Turkish Sci. Educ., vol. 15, no. 4, pp. 1-14, 2018.

[27] I. Ijirana and S. Supriadi, "Metacognitive Skill Profiles of Chemistry Education Students in Solving Problem at Low Ability Level," J. Pendidik. IPA Indones., vol. 7, no. 2, pp. 239-245, Jul. 2018.

[28] S. Azwar, Sikap Manusia: Teori dan Pengukurannya. Yogyakarta.: Pustaka Pelajar, 2005.

[29] Y. Herlanti, "Kesadaran Metakognitif dan Pengetahuan Metakognitif Peserta Didik Sekolah Menengah Atas dalam Mempersiapkan Ketercapaian Standar Kelulusan pada Kurikulum 2013," Cakrawala Pendidik., vol. 34, no. 3, pp. 357-367, 2015.

[30] A. Pritchard, Ways of Learning: Learning Theories and Learning Styles in the Classroom, 2nd ed. London and New York: Taylor \& Francis e-Library, 2009.

[31] H. Setiawati and A. D. Corebima, "Improving Students ' Metacognitive Skills through Science Learning by Integrating PQ4R and TPS Strategies at A Senior High School in Parepare, Indonesia," J. Turkish Sci. Educ., vol. 15 , no. 2, pp. 95-106, 2018.

[32] A. Zohar and S. Barzilai, "A review of research on metacognition in science education: current and future directions," Stud. Sci. Educ., vol. 49, no. 2, pp. 121-169, Sep. 2013.

[33] G. Schraw and D. Moshman, "Metacognitive theories," Educ. Psychol. Rev., vol. 7, no. 4, pp. 351-371, 1995.

[34] A. Rahman, "Profil Kemampuan Berpikir Kritis Dan Kemampuan Metakognitif Siswa Berdasarkan Jenis Kelamin," J. Pendidik. Biol., vol. 10, no. 1, pp. 28-43, 2018.

[35] C. Nurmaliah, "Analisis Keterampilan Metakognisi Siswa SMP Negeri Di Kota Malang Berdasarkan Kemampuan Awal, Tingkat Kelas, dan Jenis Kelamin,” J. Biol. Edukasi, vol. 1, no. 2, pp. 18-21, 2009.

[36] H. Syarifah, S. Indriwati, and A. Corebima, "Pengaruh Strategi Pembelajaran Reading Questioning and Answering (RQA) Dipadu Think Pair Share (TPS) Terhadap Keterampilan Metakognitif Siswa Laki-Laki dan Perempuan SMAN Di Kota Malang," J. Pendidik. - Teor. Penelitian, dan Pengemb., vol. 1, no. 5, pp. 801-805, 2016.

[37] S. Mahanal, "Strategi Pembelajaran Biologi, Gender Dan Pengaruhnya Terhadap Kemampuan Berpikir Kritis," in Seminar Nasional IX Pendidikan Biologi FKIP UNS, 2012, pp. 1-7.

[38] N. Ahmed, N. Ahmed, A. Wiyarsi, and R. N. Senam, "Comparison of Students' Metacognitive Skills by Gender in Chemistry," J. Pendidik. Sains, vol. 7, no. 2, 2019 